\title{
Japan overtakes Soviet Union in research spending league
}

\section{Tokyo}

JAPAN's investment in research and development continues to soar, with industry providing the lion's share, although basic science is still short of funds. Research spending rose more than 12 per cent in the last fiscal year (ending March

solar power) on the other hand remained stagnant or decreased.

Space and marine research, much of which is funded by the government, show healthy increases. But research spending in the universities, where much of Japan's basic research is carried out, did not even 1986) to surpass that

of the Soviet Union;

Japan now ranks Country

second only to the

United States, ac- Japan (1985)

cording to figures United States (1985)

from the Manage- Britain* (1983)

ment and Coordina- West Germany (1985)

tion Agency.

France (1984)

Spending on research and development

Private industry has Soviet Union (1984)

dominated recent ${ }^{*}$ The figures for Britain do not include the humanities and social sciengrowth in investment ces. The equivalent figures for Japan are 8.12 million million yen and while the share of 2.53 percent of GNP

funding for the universities and basic science continued to lag. But in the life sciences, and in particular genetic engineering, there were large increases in both the public and private sectors.

It is a characteristic feature of Japanese science and technology that research funding is provided largely by industry. As a result, the research is predominantly applied and product-oriented. Although some Western governments might be envious of such a situation, it causes great concern in Japanese government circles. The chronic national debt, which now stands at Y152 million million (nearly \$1 million million), has prevented any significant increase in government funding for basic research, and the gap in funding between basic and applied research continues to widen.

Total spending on research and development, including outlays for the humanities and social sciences, reached Y8.8 million million ( $\$ 58,000$ million), 2.8 per cent of Japan's gross national product (GNP). Nearly 80 per cent of this was nrovided hv the nriyate, sertor which increased its expenditures by 15 per cent over the previous year.

The big spenders in industry were the electronics, chemical and car industries, the electronics companies investing Y1.8 million million. Steel and ceramic industries also increased research funding by more than 25 per cent.

In the energy sector, nuclear power research rose 10 per cent to $\mathrm{Y} 350,000$ million. With electric power companies raking in profits as a result of low oil prices and the high yen, and with the government and industry holding ambitious plans for expansion of nuclear power, funding for this type of energy research scheme is bound to increase. Outlays for research on natural sources of energy (such as wind and keep up with inflation. Funding for science (including engineering and agriculture) rose a mere 1.1 per cent to $\mathrm{Y} 1$ million million. With more than 120 scientists and engineers in the universities, more than 80 per cent of these funds were swallowed up by salaries alone.

Basic science did receive a boost, but not from the government. Industry has begun to perceive the need for basic research (or at least for the kind that might

\section{London}

THE current cold spell has caused considerable disruption to the Soviet Union's already over-stretched energy supplies. With temperatures the lowest of the postStalin era, there has been inevitably an increased demand for electricity. But, even before the cold set in the situation was already serious, with rationing and staggered working hours in force in manv of the union republics (see Nature 324, $403 ; 1986)$. The Chernobyl disaster, and the shortfall of hydroelectric capacity due to the drought last summer, are being cited as the main causes. But other factors are clearly involved. A politburo meeting last August noted the need to step up the refitting and overhauling of existing power stations, the stock-piling of fuel at power stations, and, in particular, the introduction of fuel and energy-saving measures, including the "prewinter preparation of dwelling houses".

The latter point is significant. Shoddy workmanship in the construction of apartment blocks (a major target of the new policy of openness) and infrequent and inadequate maintenance are responsible

lead to applications), and privatelyfunded laboratories for basic research have been sprouting up all over the country (Nature 311, 404; 1984). Industry's contribution to basic science increased by more than 20 per cent in fiscal year 1985 to Y350,000 million, a large proportion of this coming from the chemical and pharmaceutical industries. Nevertheless, the proportion of Japan's total research and development funds allotted to basic science continues to decline. The picture in the universities is not all gloom, though, and funding for the life sciences has increased by leaps and bounds.

Prime Minister Yasuhiro Nakasone's enthusiasm for the life sciences and basic research in this field is destined to give these disciplines a further boost this year if his "Human Frontiers Science Program" gets off the ground. Promoted as Japan's answer to the US Strategic Defense Initiative and Europe's Eureka, the frontiers programme is expected to support basic research into the functions of living organisms (including man), such as mechanisms of the brain, and the nervous and immune systems. But even here Japan has its eye on future applications, such as intelligent robots and artificial muscle.

But it is not clear how the funds for such a major initiative will be raised, although tax reform and privatization of the national railways may help to boost government finances in the long term.

David Swinbanks

\section{Cold spell taking its toll in the Eastern bloc countries}

for considerable waste of heat, while, according to a spokesman for Moscow city council, many of the new blocks were simply not designed for such cold weather.

But the extra fuel needed is not readily available. Coal trains are snowed in and gales in western Siberia have brought down the exposed power lines that serve the oilfields, halting the extraction of oil.

Elsewhere in Eastern Eurone the situation has been similar, with transport paralysed, massive demands on already overstretched energy supplies. In Hungary, an inter-ministerial coordinating commission has been set up to deal with what is officially termed an "extraordinary situation", and rescue work is being undertaken jointly by Hungarian and Soviet troops. (Normally, except during Warsaw Pact exercises, Soviet army units in Hungary keep an extremely low profile.) Bulgaria, which several weeks ago had already urged stringent energy-saving including fines for excessive use, and Romania, where prolonged power cuts occur regularly every winter, expects considerable difficulties in the next few days.

Vera Rich 